\title{
INCREASING TOEFL SCORE USING MIND MAPPING METHOD
}

\author{
Evan Afri $^{1}$, Muhammad Khoiruddin Harahap ${ }^{2}$ \\ 1, 2Ganesha Polytechnic Medan, Indonesia \\ E-mail: evanafri@gmail.com
}

Received: 13 November 2019

Accepted: 12 December 2019

\begin{abstract}
English as an international language has become an important requirement in the world of education, giving access to information and technology. English is spoken as a first or second language in various countries and this indicates that English is likely to remain a globally dominant language for many years to come. Standardization of English proficiency is measured by a TOEFL score in stages, especially for students who are looking for scholarships at home and abroad, making the TOEFL score a major requirement. International scholarships require a minimum TOEFL score of 550. This study is concerned with Mind Mapping strategies or techniques to improve TOEFL scores. The implementation of this method is carried out for students of Ganesha Polytechnic as a research sample through two stages, namely Pre-Test, and Final-Test. The number of samples used in this study is as many as 300 students consisting of semester 1 , semester 3 and semester 5 . Based on the results of trials with the Mind Mapping method with a duration of 3 months there is an increase in the TOEFL score between Pre-Test and Final Test.
\end{abstract}

Keywords: Mind Mapping, TOEFL, Proficiency

\section{Introduction}

English is one of the five International languages recognized by the United Nations, out of Arabic, French, German and Mandarin. One of the weaknesses of the Indonesian people in speaking English is that English is not the mother tongue in Indonesia. This factor is so because Indonesia was once under the Dutch colonialism. This is in contrast with countries under the auspices of the Commonwealth countries using English as a second mandatory language.

The use of English teaching methods, especially in learning Standard English grammar greatly affects the achievement of students' understanding of the material provided. English grammar teaching methods obtained by students at an earlier educational level still tend to only activate one side of their brain (Pravitasari \& Fitriasih, 2014). Learning English grammar is like memorizing a row of standard formulas such as learning mathematics. For example, to learn tenses consisting of 16 types, students are offered sixteen formulas for the sixteen types of tenses, such as: Simple Present Tense with the formula of Subject + Verb 1 + Object, and so on. In fact, there is one way in which the sixteen types of tenses can be explained very easily through images called Mind Map.

Mind Mapping is helpful in the work process of the human brain which is divided into two, namely the left brain and the right one. Both hemispheres of the human brain have different tasks and ways of working. The left brain works for things related to words, numbers and lists; while the right brain works for things related to consciousness, 
imagination, color, and beauty.

This study explores the mind mapping method in answering TOEFL questions because it facilitates participants to analyze the types of questions. In answering TOEFL questions, students are given TOEFL steps as the facilitator.

Listening Comprehension is the first part of the TOEFL test material. This section consists of 50 questions in which the answer sheet is only available for each question. This listening section consists of listening to 3 types of conversation, namely:

a) Short conversation: usually consists of 2 lines and dialogue between 2 speakers. There are 30 questions with 30 answers for this type of conversation problem.

b) Long conversation: consists of several conversations between 2 people to answer questions. The number of questions for each conversation is approximately 4.

c) Long Dialogue: In this section students listen to someone talking about some problems both at campus and in everyday life.

Types of structural questions are multiple choice questions where knowledge about grammar is required. Some tips are presented below:

a) Studying sentences: to analyze what types of sentences are to be identified.

b) Studying how to complete sentences: to choose the best word to make a sentence meaningful.

c) Error analysis: to identify mistakes causing sentences meaningless.

d) Studying structural elements of a sentence: to identify the non-standard structure of English sentences.

Section 3 of the TOEFL test is Reading comprehension. This part is used to evaluate the ability of examinees to understand written texts in English. This section contains at least 5 text reading, each consisting of ten questions and the total number of the questions in this section is fifty. Examinees must complete all questions within fifty minutes. This section is related to text reading, without pictures, diagrams or other visual aids. The reading themes tested in this section are quite varied, but generally related to materials taught at universities in the United States, covering history, literature, art, architecture, geology, biology, health, astronomy, geography, and so on

The samples of this research are selected from students majoring in Informatics Management, Informatics Engineering and Accounting of Ganesha Polytechnic Medan. The students have learned English since they are in the first year and have already got adequate knowledge in English covering listening comprehension, structure and reading comprehension as the initial foundation to attend the TOEFL test.

The purpose of this study is to improve the TOEFL scores of students of Ganesha Polytechnic Medan. This study also aims to help students understand the steps in answering TOEFL questions so that they could make good preparations before attending the test.

\section{Literature Review}

\subsection{TOEFL}

TOEFL is an abbreviation of Test of English as a Foreign Language, organized by an institution in the United States called ETS (Educational Testing Service). Initially, the TOEFL was needed for students in countries whose main language was not English, but who wanted to continue their studies in countries whose official language was English, such as the United States, Canada, and Western European countries. This is needed to ensure that students from non-English speaking countries are able to attend lectures in English-speaking countries properly. 
Earlier works and researches on TOEFL have been conducted by many linguists and researchers. Noviyenty (2018) conducted a research entitled Upaya Peningkatan Kompetensi Bahasa Inggris Mahasiswa Jurusan Tarbiyah Program Studi Pendidikan Agama Islam (PAI) STAIN Curup Dan Relevansinya Terhadap TOEFL Score Sebagai Syarat Wisuda (Efforts of improving English Language Competence for Tarbiyah Department Students of Islamic Religious Education Study Program of (PAI) STAIN Curup and Its Relevance to TOEFL Score as Graduation Requirement).

She analyzes the condition of English competency of students of PAI STAIN Curup supported by TOEFL Score data in the Unit of Language Development and finds that the average score is still low, unable to reach the standard one, even though the facilities or infrastructure given to students are already good enough.

Another research related to the present study is published in the Journal of Prospective Learning FKIP Universitas Tanjungpura (Salam, 2017) entitled Toefl Antara Penting Dan Frustasi: Analisis Kebijakan "Toefl" Di Universitas Tanjungpura. (Toefl Between Importance and Frustration: "Toefl" Policy Analysis at Tanjungpura University). The result shows that the scores obtained by students are still low. There are three causing factors in this case: (1) the absence of a continuous English learning program, (2) the learning process does not use English at all in the classroom, mainly using textbooks, and (3) the absence of English learning facilities and resources such as libraries.

\subsection{Mind Mapping}

Mind Mapping is a strategy for assisting students' thinking through mental mapping of words or notions. Mind Mappings contain visual frameworks like figures, diagrams, or charts utilized to display structural knowledge. They are influential in that they assist students to communicate information because they can explain complex notions in simple, meaningful representations so that learners can expand a good comprehension of the content to be learnt. Many students struggle to learn to read and these problems keep on increasing. A mind map is a graphic organizer in which the major classes are described as chapters of larger chapters (Budd, 2004). This can be utilized to create ideas, take notes, develop notions and ideas, and enhance memory (Buzan \& Buzan, 2000). It is a powerful tool that teachers can use to enhance learning and create a foundation for learning. It is useful for visual learners as they are instruments with managing thought, leading learning, and making relationship (Stephan \& Hermus, 2007). In mind mapping strategy, educators do not have any limitation for expressing their ideas about the notions of visual and linear structure

\section{Research Method}

This research is conducted by means of a descriptive qualitative approach. (Moleong: 2000) states that qualitative research is best chosen to analyze social phenomena and regarding this, the phenomena are concerned with the difficulty of students facing the TOEFL test.

The students majoring in Informatics Management, Informatics Engineering and Accounting at Ganesha Polytechnic Medan who have ever got English Subject are chosen as the participants of this study. Although the students are not in English department, they have skill and knowledge in understanding TOEFL. The students have also to get their TOEFL score of 400 to complete the requirement of Final Task from Ganesha Polytechnic Medan. 
In collecting the data, the writer uses Pre Test and Post Test to get the TOEFL score from the students. The data are collected by scoring the TOEFL score form the scoring information (Phillips, 2003). The writer chooses scoring information from Longman Preparation Course for the TOEFL test.

\section{Result and Discussion}

\subsection{Training Preparation and Implementation}

Students participating are 77 students. The time and duration of the program are from 5 May - 6 August , 2019. The duration of 40 hours is applied in 1 hour 30 minutes per day. The learning location is at Campus of Ganesha Polytechnic Medan consisting of 15 students per class. TOEFL training is quite good and smooth. Students undergo all learning processes by referring to the teaching material by Longman Introductory Course for TOEFL for the Computer and Paper Tests (Phillips: 2003) Data regarding the test results consist of Diagnostic Pre Test, Post Test, Review Test and Final Test.

Participants attending the pre-test are dominated by students majoring in D3 Informatics Management: 75\%. While the rest are from D3 Accounting: 13\%, D3 Informatics Engineering: $12 \%$. Below are the results of the pre-test scores of 77 participants taking the pre-test

Table 1. Pre Test Score Result

\begin{tabular}{lrrrr}
\hline & Section1 & Section 2 & Section 3 & \multicolumn{1}{c}{ Score } \\
\hline Average & 36,8 & 36,4 & 44,0 & 390,5 \\
The highest score & 43 & 63 & 57 & 503 \\
The lowest score & 30 & 26 & 35 & 317 \\
Interval & 13 & 37 & 22 & 186 \\
Standard Deviation & 3,9 & 8,8 & 5,5 & 43,9
\end{tabular}

Based on the table above, it is seen that the average score is 390.5 . This indicates that the TOEFL score is still far from the standard one, that is 500 . There are only two participants who having scores above 500, the highest score. While the lowest score is 186 . When it is viewed per section, the highest score is in section 4 (reading) and the lowest in section 2 , almost the same as section 1 (listening)

Picture 1. Pre test score result

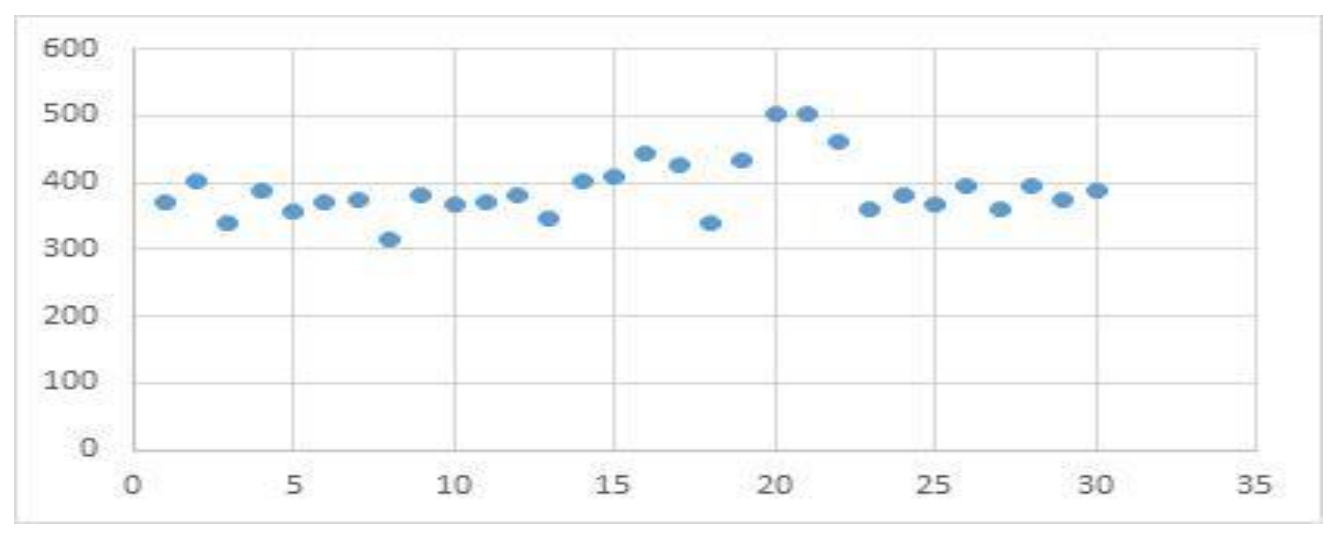


In accordance with the training plan, this training is prioritized to the section which has the lowest score, namely section 2 (Structure \& Written Expression). The training is conducted for 24 meetings or 3 months from May 2019 to August 2019.

The low score is caused by the inability to write well and correctly. According to (Amilia, 2018), writing skills are referred to as skills that require complex competence and language skills. At the very least, writing skills require reading and listening skills. Writing skills are productive skills, just like talking. However, writing skills are considered more difficult than speaking skills. This is due to complex rules in writing activities.

The material provided is divided into three categories, namely the provision of general TOEFL material, discussion of TOEFL questions, and simulations. In section 1 or listening there are 50 questions and there are 3 types of questions: short conversation, long conversation and the third is a long story (Long Talk). In the second section there are two types, namely questions in the form of structure (Sentence Completion) and Written Expression (Error Identification) consisting of 40 questions. In the structure section students are required to choose the right answer to the multiple choice problem. In the structure completion section students are instructed to analyze grammar regarding tenses, prepositions, and spellings that are refined in English. And the third is Reading Comprehension of 50 questions in the forms of reading text and vocabulary

After the pre-test and core activities (training) are carried out, a post-test is conducted. This activity is one of a series of TOEFL training that determines the success or failure of this training. The success of the TOEFL training is marked by an increase in the participants' TOEFL score from the previous test, namely the pre-test. If there is an increase, the results of the post-test are greater than the pre-test, then this training is considered successful. Conversely, if the average participants experience a decline, this training is not successful. below are the scores of the TOEFL training post test results compared with the pre-test results.

Picture 2. Pre-test and post test scores

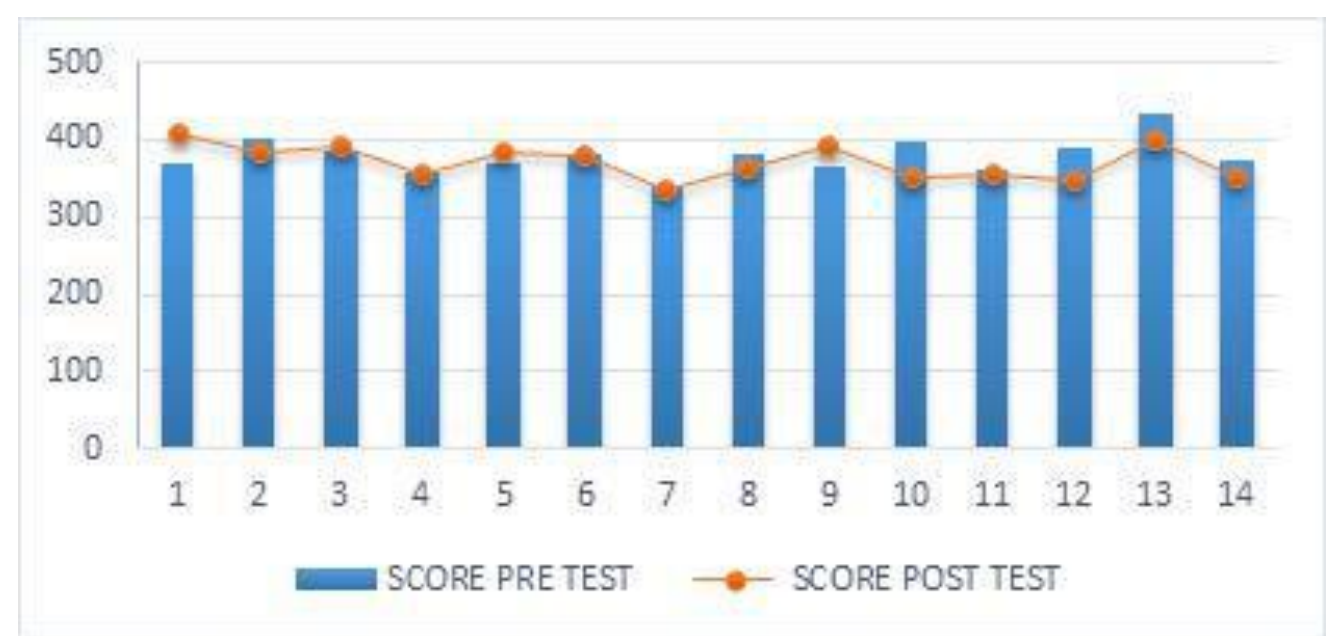

Source: Data process, 2019

Overall, of the 77 participants who take part in the training and post-test, students obtain an increase in their TOEFL scores. In contrast to the overall results, the score in section 2 discussed in the training increases. Here are the results of the pre-test and posttest. 
Picture 3. Pre test and post test scores

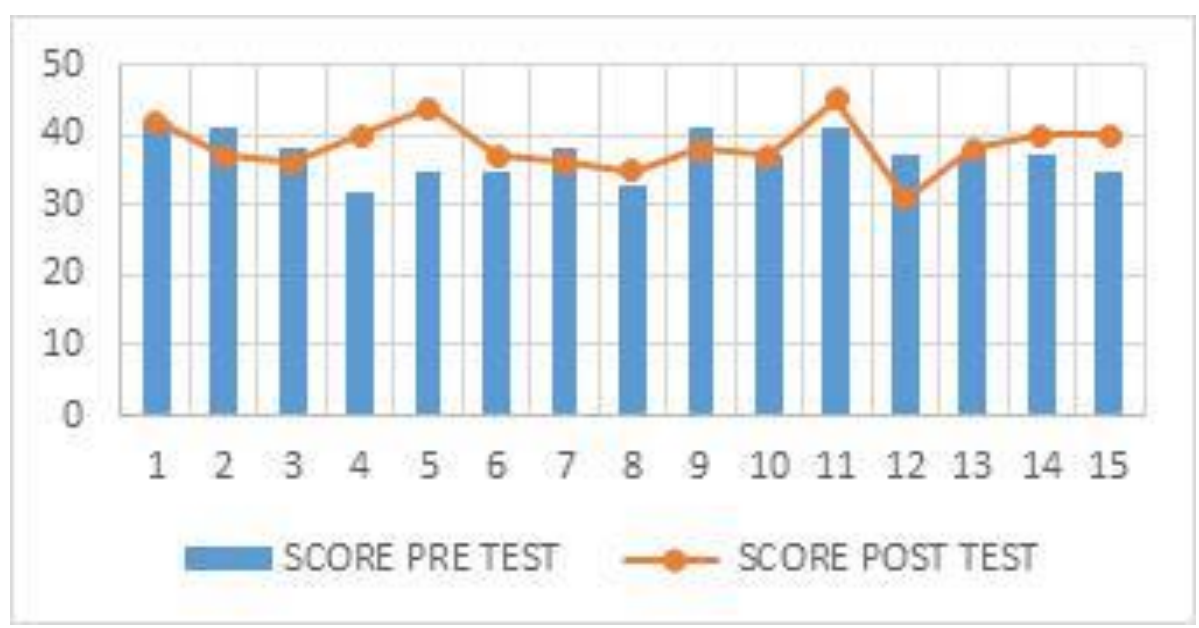

Source : data processed, 2019

Out of 77 participants taking part in the training and post-test in section 2 there are nine students having an increase, four students have a decrease and as many as two students have a decrease in this post-test compared with the results of the pre-test conducted previously. So it can be said that this training has been successful in increasing the TOEFL score of participants in this section by using the mind mapping method

Finally after the implementation of the activity has been completed, an evaluation needs to be carried out. Evaluation is carried out to find out how the participants evaluate the instructor. This assessment might also be related to the TOEFL score. If the participants' assessment of the instructor is good, then the TOEFL score should also be good, because from the instructor's side there is no problem in providing material. Conversely, if the participants' assessment of the instructor is poor then the TOEFL score is also poor. However, if the assessment is good, but the score is not satisfactory, then the problem lies on the participants, not the instructor.

\section{Conclusion}

The use of mind mapping can improve the TOEFL scores and it is useful for students to be able to answer TOEFL questions. Students are more creative and get freedom to pour ideas or knowledge they absorb into an image so that things will be more easily absorbed and will be longer stored in their memory.

\section{References}

Amilia, F. (2018). Pemahaman dan Habituasi untuk Membangun Kompetensi Menulis Praktis dan IImiah. Lingua Franca: Jurnal Bahasa, Sastra, dan Pengajarannya, 26.

Budd, J. W. (2004). Employment with Human Face: Balancing Efficiency, Equity, and Voice. New York: ILR Press.

Buzan, T., \& Buzan, B. (2000). The Mind Map Book. London: BBC Worldwide Limited.

Moleong, L. (2000). Metode Penelitian Kualitatif . Bandung: Remaja Rosda Karya.

Noviyenty, L. (2018). Upaya Peningkatan Kompetensi Bahasa Inggris Mahasiswa Jurusan Tarbiyah Program Studi Pendidikan Agama Islam (PAI) STAIN Curup dan Relevansinya Terhadap Score TOEFL Sebagai Syarat Wisuda. BELAJEA : Jurnal Pendidikan Islam, Vol. 3, No. $02,168$.

Phillips, D. (2003). Longman Preparation Course for the TOEFL Test. New York: Longman. 
Pravitasari, S. G., \& Fitriasih, S. H. (2014). Pembelajaran Bahasa Inggris III berbasis Mind Map untuk meningkatkan skor TOEFL Mahasiswa STMIK Sinar Nusantara. Seminar Nasional dan Call papers UNIBA, 44.

Salam, U. (2017). Toefl Antara Penting Dan Frustasi: Analisis Kebijakan "Toefl" Di Universitas Tanungpura. JPP, 37-44.

Stephan, P., \& Hermus, C. (2007). Making art connections with graphic organizers School Arts: The Art Education for Teachers. 